Makale Gönderim Tarihi:15.03.2015 Makale Kabûl Tarihi:04.06.2015

\title{
Exploring Issues in Understanding Qualified Teacher Status in Initial Teacher Training: Case from Leeds University $^{1}$
}

\author{
Dr. Hale ERDEN
}

Near East University, Ataturk Education Faculty, Nicosia-N. Cyprus, Mersin 10 / Turkey

\begin{abstract}
University-tutors, school-based mentors and their trainees have been using professional teaching standards (PTS) called Qualified Teacher Status standards (QTS-s) in initial teacher training (ITT) as formal entitlement to teach in the UK context. However, users of QTS-s face certain issues regarding having a common and shared understanding of the standards, managing assessment of the trainees and using essential elements necessary for ITT. The aim of this study is to explore the issues on common and shared understanding, assessment system and essential elements of QTS-s from the perspectives of the university-tutors, school-based mentors and

\footnotetext{
${ }^{1}$ Reference number of the Grant called Community Scholarships Programme 2009/2010 from European Community is 2009/215-302.

Sorumlu Yazar. Tel: +903926802000

E-posta: halerden@gmail.com
}

(C) 2015 Kalem Eğitim ve Sağlık Hizmetleri Vakfi. Bütün Hakları Saklıdır.

ISSN: 2146-5606 
trainees as applied in the United Kingdom (UK) context. This investigation is a case study under qualitative research paradigm. Data for the study were collected through in-depth face-to-face interviews using semi-structured forms. The participants of the study were seven university-tutors, ten school-based mentors and ten trainees as three key stakeholders. Through content analysis, data were put into categories and then themes and sub-themes were identified. Findings revealed themes on questioning the QTS-s, assessment and essential. Majority of participants 'questioned the standards' and majority of them 'evidenced' that list of the QTS-s should be restructured and some new standards need to be added to the list of QTS-s using a particular format issues. It was also found that the 'mentors' and 'tutors' should manage assessment of the trainees. Managing validity, reliability and inspection facilities of the QTS-s were found to be the 'essential' parts.

Keywords: Assessment; Essential; Initial teacher training; Professional teaching standards; Qualified teacher status; Questioning the standards.

\section{Başlangıç Öğretmen Eğitiminde Nitelikli Öğretmen Statüsünü Anlamaya İlişkin Sorunları Belirlemek: Leeds Üniversitesi Örneği}

\section{$\ddot{O} z$}

İngiltere'de öğretmenlik mesleğini resmî olarak yapabilmek için başlangıç öğretmen eğitimi boyunca üniversite öğrencilerinin, eğitim fakültesindeki akademisyenlerin ve okul-temelli mentörlerin, Nitelikli Öğretmen Statüsü -Qualified Teacher Status (QTS)- adı verilen öğretmenlik meslekî standartlarını kullanmaları gerekmektedir. Aslında, Nitelikli Öğretmen Statüsü listesindeki standartları kullanan paydaşlar, ortak ve paylaşılan standartların olmasına, üniversite öğrencilerinin staj dönemlerinde değerlendirilmesinin yönetimine ve başlangıç eğitiminde gerekli temel unsurların yönetimine ilişkin sorunlarla karşılaşmaktadırlar. Bu çalışmanın amacı, ortak ve paylaşılan bir anlayışa, bu anlayışa ilişkin bir değerlendirme sistemine ve nitelikli öğretmen statüsü listesindeki standartların temel unsurlarına ilişkin üniversite öğrencilerinin, eğitim fakültesindeki akademisyenlerin ve okul-temelli mentörlerin bakış açısına göre, İngiltere bağlamında kullanılması sürecinde 
ortaya çıkan sorunları belirlemektir. Bu çalışma, nitel araştırma paradigması altında bir örnek olay incelemesidir. Çalışmaya ilişkin veriler, derinlemesine görüşmeler yoluyla yarı-yapılandırılmış görüşme formları aracılığıyla toplanmıştır. Bu çalışmaya katılan katılımcılar yedi eğitim fakültesi akademisyeni, on okul temelli mentör ve on üniversite öğrencisidir. İçerik analizi ile veriler kategorilere ayrılmıştır ve burdan da temalar ve alt temalar belirlenmiştir. Ortaya çıkarılan temalar 'nitelikli öğretmen statüsü listesindeki standartların sorgulanması', 'değerlendirme' ve 'gereklilikler' olarak belirlenmiştir. Katılımcıların birçoğu 'standartları sorgulamış' ve yine birçoğu nitelikli öğretmen statüsü listesinin tekrar şekillendirilmesi ve yeni standartların var olan listeye belirli bir formata göre eklenmesi gerektiğini bildirmiştir. Okul temelli mentörlerin ve eğitim fakültesi akademisyenlerinin, üniversite öğrencilerinin değerlendirilmesini süreç içinde birlikte yapmaları gerektiği belirlenmiştir. Nitelikli öğretmen statüsü listesinde olan standartların 'geçerliği', 'güvenirliği' ve bu listedeki standartların denetiminin 'gerekli' olduğu belirlenmiştir.

Anahtar Kelimeler: Değerlendirme; Gereklilik; Başlangıç öğretmen eğitimi; Öğretmenlik meslekî standartları; Nitelikli öğretmenlik statüsü; Standartların sorgulanması.

\section{Introduction}

ITT in the United Kingdom (UK) has increasingly been carried out through schools, higher education institutions, and employment in a school. Trainees need to manage the QTS-s to complete their induction period. The QTS-s -the formal entitlement to teach in England- can only be attained by meeting the QTS-s, referred to as the professional teaching standards in ITT in the UK. Trainees cannot advance in their career without complying with the QTS-s (Teacher Development Agency, n.d.). Martin and Cloke (2000, p.184) described the QTS as "a requirement for all those wishing to teach in a maintained school and is the baseline of National Professional Qualification in the TTA's ... framework of standards and qualifications." As White, Makkonen, and 
Steward (2009) reported that the professional teaching standards are used for developing teacher induction programs. The main profiles of those who apply the professional teaching standards are trainees and qualified teachers who are mainly school-based mentors and those employing and supporting newly qualified teachers (NQTs). The QTS-s are also helpful "to establish a common framework of expectations and ... help to promote the highest professional standards for all entrants to the teaching profession" (Training and Development Agency for Schools, 2008, p.2-3).

The development of PTS has benefits for the accreditation and inspection of teachers and for developing a number of ITT programmes offered by higher education institutions and service providers other than higher education institutions (Young, Hall and Clarke, 2007). In the UK, the government first initiated the process of developing the QTS-s in the 1980s by establishing the Council for Accreditation of Teacher Education (CATE) (Department of Education and Science (DES), 1984). The first version of the QTS-s was developed in 1994. The Secretary of State for Education in the United Kingdom organized an annual meeting of the Teacher Training Agency (TTA) in 2004. In this meeting, the 1994 version of the QTS-s was suggested for review. The revised version of the QTS-s was later published in November 2006 (Nunn, 2008).

University-tutors, school-based mentors and their trainees have been using QTS-s as formal entitlement to teach in the UK context. However, users of QTS-s face difficulties in terms of having a common 
and shared understanding of the standards, managing assessment of the trainees and using essential elements necessary for ITT.

The QTS-s has been in use for many years in the United Kingdom. Professional teaching standards for a nation are used for identifying what kind of qualifications are required for providing highly-qualified ITT programs for certification, maintaining qualifications of teachers for registration, providing continuous learning and development of teachers and inspecting teachers. Therefore, professional teaching standards provide benchmarks for entry into the teaching profession, provide benchmarks for teacher competences for full registration, provide a continuum for lifelong learning and professional development, provide a framework for self-evaluation and reflection, design and assess professional learning programs and support teachers working in other educational settings (Alibaba-Erden and Özer, 2013; The General Teaching Council for Scotland, n.d.). Such kind of study is an initial study as it reflects the perceptions of the university tutors, school-based-mentors and $4^{\text {th }}$ year trainees with interviewing technique. The purpose of this study is to explore the issues on common and shared understanding, assessment system and essential elements of QTS-s in ITT from the perspectives of the university tutors, school-based mentors, and trainees as applied in the UK context.

In order to realize its aim, this study sought answers to the following three research questions:

RQ1. What common and shared understanding do the key stake- 
holders (tutors, mentors, and trainees) have while using the QTS-s in ITT?

RQ2. To what extent is the assessment system in the QTS-s as used in ITT congruent with the aims of the QTS-s according to the key stakeholders' views?

RQ3. What are the essential elements of QTS standards as used in ITT congruent with the aims of the QTS-s according to the key stakeholders' views?

\section{Method}

\section{Research Design}

Given the nature and focus of this investigation and the research questions regarding the case study, a qualitative paradigm was conducted to investigate the application level of QTS-s for ITT in Leeds, the UK. In case studies, the researcher explores a program, an event or an activity in a comprehensive way. As a nature, this study evoked intrinsic case study as the researcher has interested in understanding a specific issue on the application level of the QTS-in ITT in a particular setting (Fraenkel and Wallen, 2010, p.430).

\section{Research Participants}

The participants of this study were seven university tutors from School of Education, University of Leeds, working as teacher trainers under the PGCE-a teaching certificate programme that teachers have to obtain to be able to teach at schools throughout the UK; ten school-based mentors teaching at ten different schools, who are graduates of various universities in the UK, whose branches are English, 
Geography, Mathematics, Science, Modern Foreign Languages, Art, ICT, History, and Music; and ten trainees from School of Education at the University of Leeds, who already had their internships at various schools in 2009-2010 fall and spring terms. In this study, these participants were considered as the three key stakeholders. The participants of this study were chosen on purpose regarding experience in prior and current QTS-s usage. Fraenkel and Wallen (2010) believed that in typical sample type of purposive sampling, researchers select among the participants who represent the whole key stakeholders. In-depth face-to-face interviews were managed for gaining valuable feedback from the core group of stakeholders who need to use the QTS-s as a requirement. It is a must for tutors and school-based mentors to use the QTS-s while instructing trainees at universities and schools. This is a similar case for tutors, school-based mentors and trainees at Leeds as well, where the length of experience of the tutors and school-based mentors with regard to the use of the QTS-s varies between 17 and 25 years; most of them have been using the QTS-s since 1994-since the beginning of the initial application of the first version of the QTS-s. This makes us to think that they are well aware of both 1994 and 2007 versions of the QTS-s. The trainees were 4th year students at the University of Leeds who were the trainees of those experienced tutors and using the QTS-s for years. Also, the school-based mentors were the graduates of various universities around Yorkshire.

\section{Research Instrumentation}

Data were collected using a semi-structured interview form de- 
veloped for the purpose of this study. Semi-structured interview forms have predetermined questions, the order of which is decided by the researcher and piloted by the educational experts from the educational sciences field (Robson, 2002). The semi-structured interview form consisted of 10 items. The items on the interview form were aimed at taking university tutors', school-based mentors', and trainees' opinions regarding the issues of the QTS-s and taking their suggestions for improving these standards. The research instruments' were piloted through getting feedback from the educational experts of the field. For piloting, the educational experts from the field of educational sciences were invited to have series of in-depth interviews with the researcher for elaborating and revising the research questions accordingly. In-depth interviewing technique was applied for data collection because this technique "involves conducting intensive individual interviews with a small number of respondents to explore their perspectives" (Boyce and Neale, 2006, p.3).

\section{Procedures}

The data for this study were collected through in-depth face-to-face interviews conducted from January 11, 2010 until April 19, 2010. The data collection process lasted between 68 minutes and 77 minutes. Tutors were interviewed in their offices individually, while trainees were interviewed in their classrooms at the Faculty of Education one-by-one. School-based mentors were interviewed individually in the staff room of the school they teach for. 


\section{Data Collection and Data Analysis}

Data were collected qualitatively using case study. Data collection method included in-depth interviews. Data were analyzed using content analysis method. Content analysis includes identifying, coding, categorizing, classifying and labeling the main occurring themes in the data (Miles and Huberman, 1994; Patton, 2002). Throughout the process, recorded interviews were transcribed. Each participant of the study was assigned an ID. Through content analysis, data were put into categories and then themes and sub-themes were identified due to the responses taken from the participants of the study. Categories, themes and sub-themes were identified manual. Two educational experts in the field of research from the University of Leeds reviewed the research instruments and the data. Based on the reviewers' comments the unclear and obscure questions were revised and the complex items were reworded. Also, the ineffective and nonfunctioning questions were discarded altogether. The participants of this study are requested to read and approve the transcripts of their interviews. The educational experts and the working group members sign interview forms at each stage of the qualitative data collection. Their ticks and comments on the interview forms verify the quality of data. Additionally tutors, mentors and trainees of the study have been the participants of the study for sharing their opinions from various angles: angle of the university tutors from the School of Education, University of Leeds; and angle of the school-based mentors who already graduated from various the UK universities; and angel of the trainees who already completed their internship periods at various schools with various school-based men- 
tors, were taken into consideration while exploring the issues on common and shared understanding, assessment system and essential elements of QTS-s. Also, the researcher in the current study has tried to remain as nonjudgmental and clear as much as possible throughout the research process and tried to stick to the ethical rules and principles, performed the evaluation as accurately as possible and reported the findings honestly. In this respect, the researcher has not commented on any of the particular issue, not presented her worldview, values and/or beliefs without touching the nature of the semi-structured interviewing, because the nature of the semi-structured interviewing allows for asking probing or additional questions to shed light on the emerging issues in line with the purpose of the study to explore in-depth findings. The interviewer constantly checked perceptions and understanding of the aim and importance of the research as well as research questions, the main idea of each interview question to avoid any possible confusion/s, if any. Similarly, the investigation of the proposed interviewed participants include seven university tutors who have been applying QTS-s since 1994, ten mentors from various branches and graduates of various universities throughout the UK and ten trainees who have internship experiences at various schools and who have worked with school-based-mentors. The larger the participants means the more representative of the data obtained. Taking perceptions of various key participants from three angles makes the study externally valid. Also, in order to increase the reliability of the research, the researcher has elaborated on every aspect of the study, described in detail the rationale of the study, design of the study and participants while collecting quali- 
tative data. At the same time, the qualitative data have been obtained through 3 angles: university-based tutors, school-based mentors, and trainees of the School of Education, who already completed an internship period. Participants from three angles have been used for the triangulation purposes. In order to fulfill audit trial, the researcher sends the semi-structured interview form to the key stakeholders in advance and gives prior information in detail about how data are collected, processesed and analyzed. Similarly, the educational experts, who identified the developmental process of the study, have been chosen on purpose. The participants of the current study represent the key stakeholders. They are chosen on purpose for representing the key stakeholders. In addition to this, the participants of the current study have been explained the key terminology and/or definitions, answered the prior/on the site questions regarding the terms and definitions at once. On the other hand, the data of this study has been transcribed, key components have been identified and then themes have been derived from these components. Sub-themes were identified using the themes. Also, the interviews were recorded and preserved with the prior permission of the participants.

\section{Results and Discussion}

The results obtained from the data collected for exploring the issues on common and shared understanding, assessment system and essential elements of QTS-s in ITT from the perspectives of the university tutors, school-based mentors, and trainees as applied in the United Kingdom (UK) context were presented in this section. 


\section{Category 1: Questioning the QTS-s}

Analysis results revealed that there were 3 themes were emerged under category 1 . Category 1 was related to questioning the QTS-s. Emerged themes were restructuring, format and adding new standards (see Table 1).

Table 1. Category 1: Questioning The QTS-S, Its Themes and Sub-Themes

\begin{tabular}{llccccc}
\hline $\begin{array}{c}\text { No. and } \\
\text { Name of } \\
\text { Themes }\end{array}$ & Name of Sub-themes & 20 & 22 & 15 & 57 \\
\hline Theme 1: & 1.Removing some standards & 14 & 18 & 13 & 45 \\
Restructuring & 2.Modification and narrowing down the existing standards & 34 & 40 & 28 & 102 \\
\hline & Total & 8 & 9 & 6 & 23 \\
Theme 2: & 1.Timing for Modification & 5 & 9 & 4 & 18 \\
Format & 2. Simplified and user-friendly standards & 4 & 3 & 3 & 10 \\
& 3.Written examples of each standard for each subject & 17 & 21 & 13 & 51 \\
\hline Theme 3: & Total & 12 & 22 & 16 & 50 \\
Adding New & 1.ICT usage & 12 & 22 & 16 & 50 \\
Standard Items & Total & 12 & & \\
\hline
\end{tabular}

The first emerging theme was restructuring. The mentioned theme had 2 sub-themes. The sub-theme on removing some standards was coded 20 times by tutors, 22 times by mentors and 15 times by trainees. Also, the sub-theme on modification and narrowing down the existing standards was coded 14 times by tutors, 18 times by mentors and 13 times by trainees. The theme format had 3 sub-themes. The sub-theme timing for modification was coded 8 times by tutors, 9 times by mentors and 6 times by trainees. The next sub-theme simplified and user-friendly standards was coded 5 times by tutors, 9 times by mentors 
and 4 times by trainees. The sub-theme written examples of each standard for each subject was coded 4 times by tutors, 3 times by mentors and 3 times by trainees. Similarly, the theme adding new standard items had a sub-theme, called ICT usage. The sub-theme ICT usage was coded 12 times by tutors, 22 times by mentors and 16 times by trainees.

The student profiles have been changing constantly and QTS-s needs to be revised, restructured, and modified. They should also be simplified and user-friendly. Modification was suggested to be between 3-5 years. Most of the mentors suggested that some new standards should be written under the dimension of the ICT usage. Also, each teacher and trainee need to deal with the same list of the QTS-s. However, it has been suggested that written examples of each standard for each subject matter should be published. It has also been suggested that use of ICT should be a separate dimension and new standards for ICT usage should be written. Therefore, the standard item including ICT in it should be rearranged by omitting ICT in it. ICT as a separate dimension should have standards such as awareness of ICT usage, knowing how to use ICT effectively, arranging teaching and learning atmosphere for using ICT as an alternative to teaching and learning methods and strategies. Kington, Harris and Leask (2002, p.35) emphasize that "it is not necessarily the technology that has to be innovative, but the approach to teaching and learning must be". This shows that standards in relation to the ICT usage should be revised and rewritten clearly. Gulbahar and Guven (2008) reveal that ICT usage has 
limitations in terms of teachers' deficiency in showing necessary usage skills and insufficient infrastructure at schools. Therefore, policy makers and teachers have responsibility in planning and designing the ICT usage throughout the schools and classes.

\section{Category 2: Assessing the QTS-s}

Analysis results showed that there were 2 themes were emerged under category 2. Category 2 was related to the assessment of the QTS-s. Emerged themes were mentor assessment and tutor assessment (see Table 2).

Table 2. Category 2: Assessing the QTS-s, Themes and Sub-themes of Category 2

\begin{tabular}{|c|c|c|c|c|c|}
\hline $\begin{array}{l}\text { No. and } \\
\text { Name of } \\
\text { Themes }\end{array}$ & Name of Sub-themes & $\stackrel{\mathscr{0}}{\stackrel{0}{\Xi}}$ & 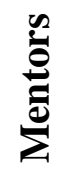 & 串 & $\stackrel{\bar{\sigma}}{\stackrel{\sigma}{\theta}}$ \\
\hline Theme 4: & 1. Professional Judgment & 12 & 18 & 9 & 39 \\
\hline Mentor & 2. Regular Assessment & 11 & 16 & 10 & 37 \\
\hline Assessment & Total & 23 & 34 & 19 & 76 \\
\hline Theme 5: & 1. Moderation role & 13 & 12 & 10 & 35 \\
\hline Tutor & 2. Negotiation between tutors and mentors & 10 & 12 & 12 & 34 \\
\hline Assessment & Total & 23 & 24 & 22 & 69 \\
\hline
\end{tabular}

The theme mentor assessment had 2 sub-themes, professional judgment and regular assessment. Sub-theme professional judgment was coded 12 times by tutors, 18 times by mentors and 9 times by trainees. The sub-theme regular assessment was coded 11 times by tutors, 16 times by mentors and 10 times by trainees. Next theme, tutor assessment, had 2 sub-themes, moderation role and negotiation 
between tutors and mentors. The sub-theme moderation role was coded 13 times by tutors, 12 times by mentors and 10 times by trainees. The next sub-theme negotiation between tutors and mentors was coded 10 times by tutors, 12 times by mentors and 12 times by trainees.

The discussion should be made on assessing the competent trainees. This is related to the argument on whether the trainee needs to fulfil all of the QTS-s. As Martin and Cloke (2000) claimed, very competent trainees may not fulfil all the QTS-s as they may fail to manage at least one standard. Thus, they are not awarded the QTS, while some medium-competency trainees are awarded the QTS just because they seem to manage all the standards. The point made here is that the judgments of the mentors are very vital in deciding among very competent, mid-competent and less-competent trainees. Awarding the QTS to a mid-competent teacher but not to a very competent teacher cannot point to a fair assessment system. Martin and Cloke (2000, p.186) emphasized that assessors need to "look beyond the qualifications". In a report published by the TES (1998), it has been put forward that a checklist of competences cannot necessarily show the competence of the trainees. There may be teachers who do not meet all the standards but seem very creative in their teaching, and everyone can observe the students learning easily in these trainees' classes. If a trainee feels that the professional standards narrow down his/her teaching, then, he/she may not desire to comply with all the standards. As Sachs (2003, p.185) revealed, teachers in "remote areas, difficult schools, or multi-age settings" may not give their full attention to the standards but 
can still be creative in their teaching. The application of professional teaching standards should not be barriers to the creativity of teachers but should always help teachers to go one step further when applying the standards. There may be some limitations in using some standards due to time and setting. Therefore, instead of being sceptical and insisting that teachers should show every standard in their teaching, it is better to leave the teaching to the teachers and trust their creativity. Dewey (1916, p.104) mentioned that having "ends lying outside our activities ... limit intelligence; they are not the expression of mind in foresight, observation, and choice of the better among alternative possibilities." Dewey (1916, p.104) added, "they limit intelligence because, given ready-made, they must be imposed by some authority external to intelligence, leaving to the latter nothing but a mechanical choice of means". Dewey, a twentieth-century-philosopher, emphasized that even in those years, limiting the capacity and talent of the teachers in a way, putting every individual in one-type, through showing signs of all the standards for instance, is not a good way. It is better to help teachers find alternative possibilities among the options they have in their particular teaching conditions. It is better not to limit the capacity and talent of the teachers with a list of teaching standards but instead look beyond their conditions while assessing them.

Thus, Tedder and Lawy (2009, p.413) asserted the issue on the lack of clarity within the meaning of mentorship. They found, "The direction of government reforms has been to make mentoring a part of the formal assessment of trainee teachers against national standards, 
and the ... OfSTED inspection reports emphasize an approach to mentoring that is target-driven and judgemental." They added, "Official rhetoric uses the language of 'excellence' or 'best practice'. However, the research on mentoring practices within colleges suggests there is a diversity of ideas and approaches, many of which emphasize the developmental character of good mentoring". Due to the dilemmas illustrated between the documents of government and OfSTED (the Office for Standards in Education, Children's Services and Skills), then the finding on mentor assessment seemed more judgmental should not be totally rejected.

\section{Category 3: Essential Elements of the QTS-s}

Analysis results showed that 3 themes were emerged under category 3. Category 3 was related to the essential elements of the QTS-s (see Table 3).

The first emerging theme under category 3 was validity. Next 2 themes emerged under category 3 were reliability and the OfSTED's inspection. The theme validity had 2 sub-themes, which were called Essential for managing the QTS-s and Essential for supplying fair and acceptable assessment of trainees. The sub-theme on Essential for managing the QTS-s was coded 8 times by tutors, 10 times by mentors and 10 times by trainees. The next sub-theme on essential for supplying fair and acceptable assessment of trainees was coded 12 times by tutors, 8 times by mentors and 11 times by trainees. The theme reliability had 2 sub-themes called minimal requirement and essential for having trust and consistent assessment of trainees. The sub-theme on minimal re- 
quirement was coded 9 times by tutors, 9 times by mentors and 12 times by trainees. The sub-theme on essential for having trust and consistent assessment of trainees was coded 9 times by tutors, 9 times by mentors and 10 times by trainees. The next theme on the OfSTED's inspection had 3 sub-themes, which were the third eye, the inspectors of OfSTED as well as regular inspection, good relationship and negatively affected grades. Only trainees coded the theme on OfSTED's inspection. The sub-theme on the third eye was coded 19 times: the next sub-theme on the inspectors of OfSTED was coded 17 times and the sub-theme on good relationship and negatively affected grades was coded 18 times.

Table 3. Category 3: The Essential Elements of the QTS-s, Themes and Sub-themes of Category 3

\begin{tabular}{|c|c|c|c|c|c|}
\hline $\begin{array}{l}\text { No. and } \\
\text { Name of } \\
\text { Themes }\end{array}$ & Name of Sub-themes & 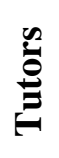 & 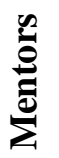 & 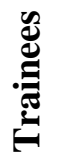 & $\stackrel{\text { కే }}{0}$ \\
\hline \multirow{3}{*}{$\begin{array}{l}\text { Theme 6: } \\
\text { Validity }\end{array}$} & 1. Essential for managing the QTS-s & 8 & 10 & 10 & 28 \\
\hline & $\begin{array}{l}\text { 2. Essential for supplying fair and acceptable assessment } \\
\text { of trainees }\end{array}$ & 12 & 8 & 11 & 31 \\
\hline & Total & 20 & 18 & 21 & 59 \\
\hline \multirow{3}{*}{$\begin{array}{l}\text { Theme 2: } \\
\text { Reliability }\end{array}$} & 1. Minimal requirement & 9 & 9 & 12 & 30 \\
\hline & $\begin{array}{l}\text { 2. Essential for having trust and consistent assessment of } \\
\text { trainees }\end{array}$ & 9 & 9 & 10 & 28 \\
\hline & Total & 18 & 18 & 22 & 58 \\
\hline \multirow{4}{*}{$\begin{array}{l}\text { Theme 3: } \\
\text { The } \\
\text { OfSTED's } \\
\text { inspection }\end{array}$} & 1. Third eye & 0 & 18 & 19 & 19 \\
\hline & 2. Inspectors of the OfSTED & 0 & 0 & 17 & 17 \\
\hline & $\begin{array}{l}\text { 3. Regular inspection, good relationship and negatively } \\
\text { affected grades }\end{array}$ & 0 & 0 & 18 & 18 \\
\hline & Total & 0 & 0 & 54 & 54 \\
\hline
\end{tabular}

With regard to supplying validity and reliability issues, discus- 
sions are mainly on how valid and how reliable the trainee assessment is. In terms of the validity, Martin and Cloke (2000, p.186) believed that "the standards do not capture the profession of teaching". The conditions of the teachers, students as well as the teaching and learning atmosphere can lead a very competent teacher to take some steps apart from managing all the standards. Competency should sometimes be regarded as an art and talent, but not obeying a list of competences. Tutors emphasized the validity issue. They believed that mentors and tutors know the students very well instinctively. Trainees who teach at difficult schools, multi-aged classrooms and/or remote areas of the country may not cover all of the standards in their teachings, but get their full attention to the learning of the students and be creative in their teachings. Due to difficulties faced by the trainees, they may not manage the set of standards, but they are still creative and talented enough to promote students' learning. Therefore, it is better to examine the conditions of the trainees before failing them when they cannot manage all of the QTS-s.

Williams (1997) stated that teacher education providers have been subjected to cycles of inspection under the direction of OfSTED. Alibaba-Erden (2014a) found that learning is a cycle of monitoring, cycle of assessment and cycle of feedback. This reveals that learning should be in clear cycle harmony with monitoring the learning, assessment of the learning and then giving feedback after assessing the learning. Cohen (1976) technically described reliability of the assessment of the trainees as ability. University-based tutors and 
school-based mentors should obtain similar testing scores after assessing the same trainee. Similar or nearly similar test scores should be obtained when assessing the same trainee through various alternative assessment techniques. Alternative assessment techniques can either be portfolios, observation, questioning, assignments and projects (SQA Accreditation, 2008). Reliability of the assessment was described as the "consistency" (Oppenheim, 1992, p.14). The results of this study revealed that trainees have strong emphasis on having a "third eye" in their assessment for supplying the reliability. What they suggest is that apart from the assessment by the mentors and the moderation by the tutors, they have mostly suggested that their performance at schools needs to be inspected by the inspectors of the OfSTED every semester. In a way, they believe that this system will be a scientific assessment model for them. They claim that such a system will not only increase the reliability of the assessment of the trainees but also will stop the unfair assessment which possibly to be made due to the good relationship between the trainees and the assessors. Campbell and Husbands (2000, p.39) stated that method of inspection of the OfSTED inspectors was "insufficiently reliable". It is highly interesting to find out that only trainees emphasized the importance of third eye on their assessment to increase the reliability. At the same way, having video recordings of the trainee assessment has been suggested. Video evidences can be a solution to solve most of reliability and validity issues as well as the third eye suggestion of the trainees.

With regard to the form of assessment, Hager and Butler (1996, 
p.369) mentioned about two models of assessment as "the scientific" and "the judgemental" models. The scientific model, they claimed, is "the traditional model which has dominated educational assessment" and the judgmental model is the model that "encompasses the best understanding of what is involved in the profession or occupation. Martin and Cloke (2000, p.185) commented on the judgmental model and said that this model has a benefit in "guiding the curriculum development and the assessment technology. Therefore, "in a judgemental model, assessment centres on the integration of theory and practice, assessment recognises the context-dependent aspects of knowledge, in contrast to the scientific model where assessment is theory focused and uses closed problems with definite answers". On the other hand, Martin (1997) believed that among two models, the judgemental model has been more suitable for ITE as the mentioned model strongly suggests a different and more qualitative approach to assessment when compared to the scientific model. The type of the assessment they use is called judgmental assessment, but not scientific. Scientific assessment is not the type of assessment found out in the current study. Judgmental-moderator model they use is good for assessing the trainees. Knowing students very well while assessing them is a good point to emphasize, as difference between talented and weak trainees should be identified. However, it has been emphasized that those who assess should be a knowledgeable experts and active leaders of their assessment (Alibaba-Erden, 2014a; Alibaba-Erden, 2014b).

Mentors generally do not use scientific judgments while asses- 
sing the trainees; instead they use their personal judgments. Tutors are seen as negotiators between themselves and mentors. In a way, they approve the personal judgments of mentors. Personal judgement of the mentors and the tutors can lead to invalid and unreliable assessment. It is recommended OfSTED inspectors also assess the trainees. However, due to the time constraint OfSTED inspectors may face, video evidence of the teaching practice of the trainees will have much help. Supplementing the mentors' and tutors' assessment with the assessment by the OfSTED inspectors will be like the three legs of a table. Triangulation of the assessment (tutors, mentors and inspectors of the OfSTED) results will not only increase the reliability, but validity as well. The trainees name this triangulation as the $3^{\text {rd }}$ eye. OfSTED has been suggested to expand its functions, either through personal or video observations, for covering the triangulation issue as a basis of essential elements of QTS.

\section{Conclusion}

The qualitative data yielded category 1, questioning the QTS-s. This category involved themes restructuring, format and adding new standard items. The theme on restructuring generated sub-themes removing some standards, modification and narrowing down the existing standards. The theme on format yielded sub-themes on timing for modification, simplified and user-friendly standards and written examples of each standard for each subject. Also, the theme on adding new standard items involved sub-theme information and communication technology usage. 
The qualitative data involved category 2, assessing the QTS-s. This category yielded themes mentor assessment and tutor assessment. The theme on mentor assessment had sub-themes called professional judgement and regular assessment. Also, the theme on tutor assessment yielded sub-themes moderation role and negotiation between tutors and mentors.

The qualitative data generated category 3 , the essential elements of the QTS-s. This category involved themes validity, reliability and the OfSTED's inspection. The theme on validity yielded sub-themes essential for managing the QTS-s and essential for supplying fair and acceptable assessment of trainees. Additionally, the theme on reliability generated sub-themes minimal requirement and essential for having trust and consistent assessment of trainees. Finally, the theme on the OfSTED's inspection involved sub-themes third eye, inspectors of the OfSTED and regular inspection, good relationship and negatively affected grades.

As a conclusion, the QTS-s were questioned by the participants in terms of restructuring, format and adding new standard items through removing, modification and narrowing down some of the existing standards, providing written examples for each standard item for each subject area, having simplified and user-friendly standards, revising the QTS-s list within 3-5 years as well as adding new standards on ICT usage. Participants also concluded that mentors and tutors should be assessed. Mentors should be assessed by using professional judgement and regular assessment. Tutors assessment should be supplied through 
moderation and negotiation between tutors and mentors.

Validity of the QTS-s should be supplied through managing the QTS-s list and managing fair and acceptable assessment of trainees whereas reliability of the QTS-s should be managed through QTS-s being the minimal requirement and having trust and consistent assessment of trainees. It was also suggested that the OfSTED's inspectors need to organize themselves to inspeet the trainees and their inspection should be used a third eye alongside mentor and tutor assessment.

It is recommended to prepare a scale and to administer to see to what extent the teachers of various sectors, university tutors and $4^{\text {th }}$ year trainees, who completed their internship period, agree with removing some QTS-s, format of the list of the QTS-s, modifying and narrowing down the existing QTS-s, revising timing, simplified and user-friendly QTS-s, written examples of each standard for each subject, having QTS-s on ICT usage, having professional judgement, having regular assessment, having moderation role and negotiating between tutors and mentors.

\section{References}

Alibaba-Erden, H. (2014a). A proposed national framework for professional teaching standards in North Cyprus. Unpublished doctoral thesis, Eastern Mediterranean University.

Alibaba-Erden, H. (2014b). Professional teaching standards' system: A proposed national framework. Saarbrücken: Scholar's Press. 
Alibaba-Erden, H. and Özer, B. (2013). Identifying professional teaching standards using Rasch model analysis: The case of Northern Cyprus. Egitim Arastirmalari-Eurosian Journal of Educational Research, 53, 175-196.

Boyce, C., and Neale, P. (2006). Conducting in-depth interviews: A guide for designing and conducting in-depth interviews for evaluation input. Pathfinder International. Retrieved January, 29, 2010 from,

http://www2.pathfinder.org/site/DocServer/m_e_tool_series_ind epth_interviews.pdf.

Cohen, L. (1976). Educational research in classrooms and schools. London: Harper and Row.

Campbell, J., and Husbands, C. (2000). On the reliability of OFSTED inspection of initial teacher training: A case study. British Educational Research Journal, 26(1), 39-48. doi: 10.1080/014119200109507

Department of Education and Science. (1984). Circular 3/84 Initial teacher training: Approval of courses. London: DES.

Dewey, J. (1916). Democracy and education. New York: The Free Press.

Fraenkel, J. R., and Wallen, N. E. (2010). How to design and evaluate research in education. (7th. ed.). Singapore: McGRaw Hill Publications.

The General Teaching Council for Scotland. (n.d.). Revised Professional Standards. Retrieved December 21, 2009 from, http://www.gtcs.org.uk/standards/revised-professional-standards .aspx. 
Gulbahar, Y., and Guven, I. (2008). A survey on ICT usage and the perceptions of social studies teachers in Turkey. Educational Technology and Society, 11(3), 37-51. Retrieved February, 11, 2010 from,

http://www.ifets.info/journals/11_3/4.pdf.

Hager, P., and Butler, J. (1996). Two models of educational assessment. Assessment and Evaluation in Higher Education, 21(4), 367-378. doi: 10.1080/0260293960210407

Kington, A., Harris, S. and Leask, M. (2002). Innovative practice using ICT in schools: findings in two case studies. Management in Education, 16(1), 31-35.

doi: 10.1177/08920206020160010801

Martin, S. (1997). Two models of educational assessment: A response from initial teacher education: If the cap fits ... Assessment and Evaluation in Higher Education, 22(3), 337-343.

doi: 10.1080/0260293970220307

Martin, S., and Cloke, C. (2000). Standards for the award of qualified teacher status: Reflections on assessment implications. Assessment and Evaluation in Higher Education, 25(2), 183-190. doi: $10.1080 / 713611425$

Miles, M., and Huberman, M. (1994). Qualitative data analysis. Beverly Hills: Sage Publications.

Nunn, J. (2008). From the interface of policy and practices: Revising the standards for qualified teacher status in England. A traveller's tale. Unpublished doctor of education thesis, Roehampton University.

Oppenheim, A. (1992). Questionnaire design, interviewing and attitude measurement. London: Pinter. 
Patton, M., Q. (2002). Qualitative research and evaluation methods $\left(3^{\text {rd }}\right.$ ed.). Thousands Oaks, CA: Sage Publications.

Robson, C. (2002). Real world research. A resource for social scientists and practitioner researchers ( $2^{\text {nd }} \mathrm{ed}$.). Singapore: Blackwell Publishing.

Sachs, J. (2003). Teacher Professional Standards: Controlling or developing teaching? Teachers and Teaching, 9(2), 175-186. doi: 10.1080/13540600309373

SQA Accreditation. (2008). Guide to assessing: Workplace core skills. Retrieved December, 12, 2009 from, http://www.sqa.org.uk/files_ccc/GuideToAssessingWorkplaceC oreSkills_Aug08.pdf

Teacher Development Agency (TDA) (n.d.). Retrieved November, 5, 2009 from, http://www.tda.gov.uk/partners/ittstandards/qts_skills_tests.aspx

Tedder, M., and Lawy, R. (2009). The pursuit of 'excellence': Mentoring in further education initial teacher training in England. $J o$ urnal of Vocational Education and Training, 61(4), 413-429. doi:10.1080/13636820903363634

TES. (1998). Warning on "cloned" heads. p. 12. Retrieved March, 22, 2010 from, http://www.tes.co.uk/article.aspx?storycode $=75025$

Training and Development Agency for Schools. (2008). Professional standards for qualified teacher status and requirements for initial teacher training. (rev. ed.). Retrieved November, 18, 2009 from, www.tda.gov.uk/qts. 
Young, J., Hall, C., and Clarke, T. (2007). Challenges to university autonomy in initial teacher education programmes: The cases of England, Manitoba and British Columbia. Teaching and Teacher Education, 23(1), 81-93.

doi: $10.1016 /$ j.tate.2006.04.008

White, M. E., Makkonen, R., and Steward, K. B. (2009). A multistate review of professional teaching standards. National Center for Educational Evaluation and Regional Assistance. Institute of Education Sciences: U.S. Department of Education. Regional Educational Laboratory at WestEd.

Williams, A. (1997). Quality assessment in initial teacher education: Lessons from the 1993/94 OfSTED experience, Higher Education Quarterly, 51(2), 189-200.

doi: 10.1111/1468-2273.00034. 